\title{
Ammonium Dichromate Poisoning
}

\author{
Himanshu Kumar ${ }^{1} \cdot$ Chandrakanta Kumar ${ }^{1} \cdot \operatorname{Kanak}_{\text {Parmar }^{2}}$
}

Received: 14 October 2019 / Accepted: 30 April 2020 / Published online: 30 May 2020

(C) Dr. K C Chaudhuri Foundation 2020

To the Editor: A 2-year-old boy presented with history of multiple episodes of vomiting, copious mucoid loose stools and sluggishness after one hour of ingestion of unknown amount of an orange colored crystal-like substance kept at home for father's printing work. At presentation the child was lethargic, had severe dehydration and hypovolemic shock.

Ringer lactate infusion was started immediately according to plan C of WHO recommendation. Gastric lavage was done with normal saline. Substance which child had consumed was found to be ammonium dichromate. So, high dose of vitamin $\mathrm{C}(500 \mathrm{mg} / \mathrm{d}$, oral) and N- acetylcysteine (NAC; $150 \mathrm{mg} / \mathrm{kg}$ intravenously) were administered on day 1 only.

Complete blood counts, serum electrolytes, liver function tests, blood urea and serum creatinine were within normal limits. Microscopy of stool sample was negative for leukocytes, red blood cells, Vibrio cholerae and trophozoites. Blood chromate level was sent at Indian Institute of Toxicology and Research (IITR), Lucknow and results on day 3 showed chromate level- $71.96 \mathrm{mcg} / \mathrm{L}$ which was higher than the normal chromate of $0.1-0.16 \mathrm{mcg} / \mathrm{L}$. The child improved with treatment and the vomiting and diarrhea also subsided at the end of day 1 . He was discharged after $4 \mathrm{~d}$ of hospital stay.

Chromium $(\mathrm{Cr})$ is a strong oxidant and poisoning usually begins with gastrointestinal symptoms progressing to multiorgan failure. Lethal dose of chromium salt varies between 6 to $8 \mathrm{~g}$ in adults $[1,2]$ and $1 \mathrm{~g}$ in children. In the human body, Cr VI is reduced to $\mathrm{Cr}$ III, a non-toxic form, in the plasma but when the reducing capacity is saturated, $\mathrm{Cr}$ VI

Kanak Parmar

parmar.kanak94@gmail.com

1 Department of Pediatrics, King George's Medical University, Lucknow, India

2 King George's Medical University, Lucknow, India enters the cell and causes damage by lipid peroxidation and enzyme inhibition [3].

Shortly after oral ingestion of chromates gastrointestinal mucosa is damaged, manifesting as rice-water stools, emesis, and corrosive burns of the mouth and esophagus [3]. Systemic absorption in large doses, lead to shock with multiorgan failure especially hepato-renal involvement $[4,5]$.

Various modalities of treatment have been tried in acute dichromate poisoning including antioxidants, chelating agents, peritoneal or hemodialysis and exchange transfusion. Management of shock and dehydration is crucial especially in pediatric population. NAC can increase the excretion of chromium whereas ascorbic acid in large doses accelerates the rate of reduction of chromium VI to chromium III. Although poisoning due to chromium is mostly fatal, early treatment can save patient's life.

\section{Compliance with Ethical Standards}

Conflict of Interest None.

\section{References}

1. Baresic M, Gornik I, Radonic R, Zlopasa O, Gubarev N, Gasparovic V. Survival after severe acute chromic acid poisoning complicated with renal and liver failure. Intern Med. 2009;48:711-5.

2. Hassan A. A case report: ammonium dichromate poisoning. Biomed Res. 2007;18:35-7.

3. Meert KL, Ellis J, Aronow R, Perrin E. Acute ammonium dichromate poisoning. Ann Emerg Med. 1994;24:748-50.

4. Choi DH, Joo MD, Jun DH, Choi WI, Lee DP. Acute ammonium dichromate poisoning: a case report. J Korean Soc Emerg Med. 2004;15:201-4.

5. Hemachandar R, Gopi M, Arumugam A. Ammonium dichromate poisoning: a rare cause of acute kidney injury. Indian J Nephrol. $2014 ; 24: 380-1$.

Publisher's Note Springer Nature remains neutral with regard to jurisdictional claims in published maps and institutional affiliations. 